Ann. Parasitol. Hum. Comp., 1991, $66: \mathrm{n}^{\circ} 4,155-165$.

Mémoire.
Key-words: Plasmodium berghei. Haemosporina. Malaria. Rodents. Sporozoites. Exoerythrocytic schizonts. Merozoites. Human hepatoma cells. Subpopulations. In vitro. Suspectibility. Infection. Growth.

Mots-clés : Plasmodium berghei. Haemosporina. Malaria. Rongeurs. Sporozoïtes. Schizontes exoérythrocytaires. Mérozoïtes. Hépatome humain. Sous-populations. In vitro. Susceptibilité. Infection. Croissance.

\title{
PLASMODIUM BERGHEI: SUSCEPTIBILITY AND GROWTH CHARACTERISTICS OF HEPATOMA CELLS AS HOSTS FOR MALARIA SCHIZONTS
}

\author{
G. FRANÇOIS, I. DESOMBERE, M. WÉRY
}

\begin{abstract}
SUMMARY
Three different human hepatoma cell lines (Hep G2, London; Hep G2, Brussels; Mahlavu) have been compared with respect to susceptibility for in vitro infection with Plasmodium berghei sporozoites and subsequent development of mature schizonts and infectious merozoites. The results were very different, even with host cells derived from the same parent line. Both Hep G2 lines were able to function as host cells, but the Mahlavu line was completely refractory. Hep G2 (London) was even more susceptible

than the Hep G2-A16 clone. Hepatoma cells harbouring young exoerythrocytic forms permitted their development to mature schizonts and production of merozoites inside the intraperitoneal cavity of OF1 mice. Pronounced differences in growth parameters of subpopulations of Hep G2 cells were stated as well. Optimal conditions for in vitro culture of the most suitable cell line were identified. Finally, the seeding, plating and cloning efficiencies were determined.
\end{abstract}

\section{RÉSUMÉ : Susceptibilité et caractéristiques de croissance d'hépatome humain infecté par sporozoïtes de Plasmodium berghei.}

Trois lignées cellulaires d'hépatome humain (Hep G2, Londres; Hep G2, Bruxelles; Mahlavu) ont fait l'objet d'une comparaison de leur susceptibilité in vitro aux sporozoïtes de $P$. berghei, et du développement subséquent de ces derniers en schizontes mûrs et en mérozoïtes infectieux.

Les résultats furent très différents, même entre 2 lignées cellulaires dérivées de la même souche parentale. Les 2 lignées Hep G2 se comportèrent en cellules hôtes, tandis que la lignée Mahlavu se montra totalement réfractaire. Hep G2 (Londres) fut plus susceptible que le clône Hep G2-16.
Les cellules contenant des formes exoérythrocytaires jeunes permirent leur développement en schizontes mûrs, dont le transfert dans la cavité péritonéale de souris OF1 entraîna la production de mérozoïtes et une parasitémie.

Les sous-populations Hep G2 présentèrent une diversité marquée de leurs paramètres de croissance. Les conditions optimales pour la culture in vitro de la lignée la plus susceptible furent précisées, de même que les indices d'efficacité d'ensemencement, d'étalement et de clônage.

\section{INTRODUCTION}

Malaria research has made considerable progress since the development of in vitro methods for the cultivation of Plasmodium species (Trager and Jensen 1976; Jensen et al. 1979). Since that time it became possible to study many kinds of physiological and biochemical factors involved in the maturation of parasitic forms. However, the vast majority of this work concerned the erythrocytic stages. Indeed, the practical study of the exoerythrocytic stages is not evident. Liver tissue stages in general are not easy to observe and preparation of many sections is necessary (Wéry 1967). For the systematic study of exoery-

Laboratorium voor Protozoölogie, Instituut voor Tropische Geneeskunde, Nationalestraat 155, 2000 Antwerpen, Belgium.

Accepté le : 8 août 1991. throcytic forms primary cultures of hepatocytes were needed at first. Such models possess obvious advantages since rodent hepatocytes keep the majority of their functions in vitro in short term experiments (Landau et al., 1987). Successful cultivation of liver schizonts $(P$. yoelli) in adult rat hepatocytes was reported at the beginning of the eighties (Lambiotte et al. 1981). The development of mature $P$. falciparum schizonts in cultures of functional human hepatocytes and the release of infectious merozoites was reported somewhat later (Mazier et al. 1984). But although the life of primary hepatocytes could be gradually and considerably prolonged in vitro (Bissell et al. 1987; Muakkassah-Kelly et al. 1987), they remain more difficult

Abbreviations: Population doubling time (PDT); Foetal calf serum (FCS); Glucose lactalbumin serum haemoglobin (GLSH); Minimal essential medium (MEM); Standard error of the mean (s.e.m.). 
to handle for several reasons. First of all repeated dispersion of liver and isolation and purification of liver cells remains necessary and secondly, it is not clear whether the cycle is completed in vitro in these cells with release of merozoites (Hollingdale 1988). With the introduction of human embryonic lung fibroblasts (W138) a model system became available in which the complete exoerythrocytic development was achieved (Hollingdale et al. 1981). Sporozoites of $P$. falciparum or $P$. berghei are able to invade them and can, in the case of $P$. berghei, develop to mature schizonts, giving rise to infectious merozoites.

In most publisched work, monolayers of Hep G2 cells have been used, a line established in 1975 after a liver biopsy of a child with primary hepatoblastoma and hepatocellular carcinoma (Aden et al. 1979; Knowles et al. 1980). Their morphological characteristics and epithelial cell shape are compatible with those of liver parenchyma cells. Although the cells are considered as being chromosomally abnormal (Knowles et al. 1980) it was established that they retain the expression of many liver specific genes in vitro (Gatmaitan et al. 1983; Darlington et al. 1987) and that several biochemical and metabolic features of normal hepatocytes are exhibited (Kelly and Darlington 1989); others are lost (Buscher 1990). The asialoglycoprotein receptor on the cell surface has been characterized (Schwartz et al. 1981). A lot of published work concerning attachment and entry of sporozoites and subsequent development of the intracellular forms to mature schizonts has been performed with this permanent host cell line. In some cases a derived clone called Hep G2-A16 (Schwartz et al. 1981; Geuze et al. 1983) was used.

The advantages of this in vitro system are important. As in the case of blood forms, experimental work in vivo with exoerythrocytic forms of Plasmodium species infectious to humans e.g. is not evident and requires the availability of monkeys. The use of human hepatoma cells meets this problem. The preparation and examination of numerous sections or, alternatively, the performing of biopsies and isolation of hepatocytes (Strom et al. 1982) is no longer necessary. The cells can easily and in principle for an unlimited time be kept in laboratory conditions. They can be stored in liquid nitrogen without any difficulties. They can be infected with sporozoites of different Plasmodium species, even with the human malaria parasites $P$. vivax (Uni et al. 1985; Hollingdale et al. 1986) and P. falciparum, although sporozoites of the latter species do not develop into schizonts (Hollingdale et al. 1985; World Health Organization 1988). The system offers possibilities for testing antimalarial drugs and for the inhibiting capacities of antibodies based upon the action of anti sporozoite vaccins.

Remarkably, less attention has been paid to several properties of the hepatoma cells and their infection with Plasmodium. We report the comparison of three hepatoma lines, among which two Hep G2 lines from different origin and the Mahlavu line (from South African origin), in terms of efficiency of penetration of sporozoites of P. berghei, and schizont and merozoite development. We report the establishment of important experimental parameters, such as cell dimensions and growth characteristics, including the effects of medium factors such as foetal calf serum and preconditioning. The optimal circumstances for growth and susceptibility for infection with sporozoites are established. The seeding efficiency, plating efficiency and cloning efficiency is determined. Connected with these experiments the successful cloning of Hep G2 (London) is performed. Finally the recovery of hepatoma cells from the intraperitoneal cavity of OF1 mice is discussed in the context of the survival of the exoerythrocytic stages.

\section{MATERIALS AND METHODS}

Established cultures of the malaria vector Anopheles stephensi were kept in an insectary under standard conditions: $25^{\circ} \mathrm{C}, 85 \%$ relative air humidity and a cycle of $12 \mathrm{~h}$ illumination (Sylvania Gro-Lux lamps, $36 \mathrm{~W}$ ) and $12 \mathrm{~h}$ dark. The larvae were fed with a suspension of algae (Chlorella emersonii 211/8 h) and $10 \%$ baker's yeast and from the seventh day on the more developed stages received a mixture of cereals (Bambix, Nutricia), wheat germs (Supergermes, Gayelord Hauser) and vitamins supplemented with minerals (Supradyn, Roche). The full cycle was completed in about 3 weeks. Adult female mosquitoes were fed with the blood of mechanically infected ( $P$. berghei, ANKA strain) OF1 mice and were separated from the males after the blood meal. The mosquito forms of the parasite were allowed to develop further at $21^{\circ} \mathrm{C}$.

Dissection of a sample of 10 female mosquitoes and preparation of the midguts was performed 9 days after the infections blood meal in order to check the presence of oocysts. Twenty-one to 28 days after the feeding mature sporozoites accumulated in the salivary glands, which were aseptically dissected and suspended in a minimal volume of GLSH medium (Le Ray 1975). This suspension was cautiously smashed till disruption in a glass tissue grinder and further diluted with GLSH. In one experiment 80-120 mosquitoes were dissected.

Human hepatoma cells from different origin were adapted to our laboratory conditions: Hep G2 (Imperial College, London), Hep G2 (Université Libre de Bruxelles) and Mahlavu (Katholieke Universiteit Leuven). The three cell lines were grown in $25 \mathrm{~cm}^{2}$ sterile culture flasks (Nunc) with $5 \mathrm{ml}$ of MEM Rega 3 (Gibco, Gent, Belgium) containing $10 \%$ heat inactivated FCS (Bio-Lab, Jerusalem), $2 \mathrm{mM}$ L-glutamine (Gibco, Gent, Belgium) and antibiotics (complete MEM Rega 3). The antibiotics mixture was composed of $100 \mathrm{U}$ penicillin $/ \mathrm{ml}, 100 \mathrm{U}$ streptomycin $/ \mathrm{ml}$ and $10 \mu \mathrm{g}$ fungizone $/ \mathrm{ml}$. Alternatively, sterile chamber slides (Lab-Tek, Nunc; 8 chambers per slide) were used, with $200 \mu$ l of complete MEM Rega 3 per chamber containing the same antibiotics. When the monolayers had reached near confluence new cultures were initiated by diluting the former ones in a ratio $1: 5$. Growth occurred in optimal circumstances in a $\mathrm{CO}_{2}$-incubator (LEEC GA3N) at $37^{\circ} \mathrm{C}$, in a $\mathrm{CO}_{2}$ : air $(5 \%$ : $95 \%)$ atmosphere and at approximately $99 \%$ relative humidity.

At the first day of an experiment the hepatoma cell monolayers were carefully washed with complete MEM Rega 3 and incubated for exactly 2 hours with a $P$. berghei sporozoite suspension in GLSH medium $\left(160 \mu \mathrm{l} / 25 \mathrm{~cm}^{2}\right.$ culture flask or $40 \mu \mathrm{l} /$ chamber $)$. The majority of the infectious sporozoites has penetrated the host 
cells within that time (Zavala et al. 1985). Analogous methods have been described elsewhere (Millet et al. 1986). After another rinsing procedure the infected cells were incubated with complete MEM Rega 3 medium for 58 to 72 hours. Other authors have worked within about the same time range (Suhrbier et al. 1989a).

The cells on the chamber slides were fixed with methanol and stained with Giemsa solution, after removing the plastic chambers from the glass slides. Three series of 500 hepatoma cells were counted (Leitz Laborlux D microscope, $500 \mathrm{x}$, immersion oil, blue filter) and the mean ratio of infected cells containing mature schizonts was determined.

The cells in the culture flasks were treated with a $0.25 \%$ trypsine solution (Gibco BRL, Gent) during $30 \mathrm{~min}$ at $37^{\circ} \mathrm{C}$. The detached cells were suspended in complete MEM Rega 3, spun down at $800 \mathrm{~g}$ during $5 \mathrm{~min}$ and washed two times. The pellet was resuspended in $0.3 \mathrm{ml}$ of complete MEM Rega 3 and intraperitoneally injected in six-week-old female OF1 mice (IFFA Credo, Brussel). Five to 12 days post infection, thin smears were made with tail blood, fixed with methanol and Giemsa stained. Mean parasitaemias were calculated after counting 10,000 red blood cells.

The usefulness of the three hepatoma cell lines was examined by evaluating the ratios of the cells in chamber slides containing mature schizonts and the parasitaemias obtained in mice after i.p. injection of exoerythrocytic forms.

The volume of the selected hepatoma cells was determined as follows. Monolayers were trypsinized, washed and suspended. One hundred arbitrary chosen cells were observed under the microscope $(400 \mathrm{x})$ and considered as spheres or as ellipsoids, depending on their shape. Their dimensions were carefully measured: the radius in the case of a sphere, the small and the large diameter in the case of an ellipsoid. The corresponding volumes and the overall mean were calculated, using the appropriate formulas.

The growth curve of the Hep G2 (London) cells was established at defined time intervals after inoculation. At each point 4 cultures were trypsinized. The cells were washed and resuspended with a needle in $5 \mathrm{ml}$ of fresh MEM Rega 3. The cell density of each culture was counted 4 times in an improved double Neubauer chamber. The obtained curve was analysed and the composing parts were described.

The effect of the presence of FCS on the growth of Hep G2 cells was examined by administering a range of concentrations between 0 and $10 \%$ in MEM Rega 3 supplemented with $1 \%$ of L-glutamine to 7 groups of four-day-old cultures. At the start of the experiment the initial cell density in $10 \%$ FCS was measured in an improved double Neubauer chamber and compared with the cell densities obtained after $48 \mathrm{~h}$ in respectively $0,2,4,6,8$ and $10 \%$ FCS.

The question whether the growth of Hep G2 cells was influenced by infection with $P$. berghei sporozoites or not was answered by comparing the numbers of cells present in cultures incubated for $2 \mathrm{~h}$ in a sporozoite suspension with the corresponding numbers in control cultures. The cells were counted in an improved double Neubauer chamber after $58 \mathrm{~h}$ of culture.

The dependency of the development of the exoerythrocytic forms of $P$. berghei in Hep G2 cells on the age of the host cells was monitored by infecting the host cells with sporozoites at different time intervals after initiating new cultures. After $58 \mathrm{~h}$ OF1 mice were intraperitoneally injected with trypsinized, washed and resuspended cells. Eight days later thin smears were made with tail blood and the parasitaemias were measured after Giemsa staining.

The seeding efficiency of the Hep G2 (London) cells was determined as the proportion between the number of recovered adherent cells and the number of seeded cells when plating out a cell suspension at high cell densities (e.g. $2 \times 10^{2}$ cells $/ \mathrm{cm}^{2}$ ) (Freshney 1987). A trypsinized culture was washed and diluted until a concentration of $50 \times 10^{4}$ cells $/ 5 \mathrm{ml}$ was obtained. New cultures were initiated with this inoculum, corresponding with $2 \times 10^{2}$ cells $/ \mathrm{cm}^{2}$. After $20 \mathrm{~h}$ all cultures were washed and the numbers of recovered cells were counted. All countings were performed in a improved double Neubauer chamber.

The plating efficiency was defined as the proportion between the number of colonies formed after plating out a single cell suspension at lower cell densities $\left(2-50\right.$ cells $\left./ \mathrm{cm}^{2}\right)$ (Freshney 1987). A dilution of Hep G2 cells containing 10 cells/100 $\mu$ l $(35.7$ cells $/ \mathrm{cm}^{2}$ ) was prepared and used as inoculum for new cultures in a microtiter plate (Falcon, MicroTest III). The formation of colonies was observed under an inverted microscope (Leitz Diavert). In a second experiment a series of dilutions between 50 and $500 / \mathrm{cm}^{2}$ was used as inoculum in order to establish the lower limit for colony formation. The same type of experiment was performed in 24 wells multidishes (Nunclon, Nunc).

Cloning of the Hep G2 (London) cells was performed in a 96 wells microtiter plate with a dilution of a four-day-old culture, prepared in three steps and containing 1 cell $/ 200 \mu \mathrm{l}\left(3.6 \mathrm{cells} / \mathrm{cm}^{2}\right)$. No special means such as cloning rings (Turner and Turner 1980) were used. Cell growth was monitored and colony formation was observed after 4, 8, 15, 21 and 29 days of culture. The cloning efficiency was determined based upon the results of this experiment.

The stimulating or inhibiting effect of pre-conditioned medium on the growth of Hep G2 (London) cells was monitored by seeding a suspension containing 1 cell/100 $\mu$ lin the wells of a 96 wells microtiter plate. Cell adherence on the substrate and formation of colonies was observed after 6 and 14 days of culture respectively.

The question whether the rise of the $P$. berghei parasitaemia in OF1 mice was dependent on the presence of intraperitoneally injected Hep G2 (London) cells was answered in the following experiment. Five female OF1 mice ( 6 weeks old) were i.p. injected with a Hep G2 (London) cell suspension. Immediately afterwards they were infected with blood forms of $P$. berghei, together with 5 control mice. After 8 days thin smears were made with tail blood from both groups and Giemsa stained.

The survival of Hep G2 (London) cells in the intraperitoneal cavity of OF1 mice was tested as follows. Twenty-four cell cultures $\left(175 \mathrm{~cm}^{2}\right)$ were trypsinized, washed, suspended, counted and i.p. injected in 24 corresponding OF1. After a series of defined time intervals the cavities were rinsed with MEM Rega 3 and the obtained suspensions were reseeded in culture flasks. Twenty-four hours later the cells were observed, harvested and counted again. In the experiment immediately succeeding the former one, the recovered cells were seeded in $25 \mathrm{~cm}^{2}$ culture flasks and allowed to grow till near confluence was reached. At that time a dilution of 1:5 was made and used as inoculum for subcultures.

In several cases, the results of the experiments were evaluated by means of a one-way analysis of variance (ANOVA). It was preferred to express the significance levels of the differences numerically, instead of comparing them with previously fixed significance tresholds. All calculations were made with the aid of the Statgraphics program (PLUS WARE, STSC).

\section{RESULTS}

The results of the comparison between the numbers of full-grown exoerythrocytic schizonts produced in the cell lines Hep G2 (London), Hep G2 (Brussels) and Mahlavu are given in Table $I$. All results point to a different degree of susceptibility of the 3 lines. Clearly, the Hep G2 (London) line can more easily be infected with $P$. berghei sporozoites than the Hep G2 (Brussels) line and the Mahlavu line apparently cannot be infected at all. These results 
TABLE I. - Numbers of mature schizonts grown in human hepatoma cell monolayers, 58 h p.i. with sporozoites of Plasmodium berghei. Mean values \pm s.e.m. $(\mathrm{n}=7)$. Sporozoites in GLSH medium, hepatoma cells in complexe MEM Rega 3.

\begin{tabular}{lcc}
\hline Cell line & $\begin{array}{c}\text { \# of schizonts in } \\
500 \text { hepatoma cells }\end{array}$ & $\begin{array}{c}\text { \% of infected } \\
\text { hepatoma cells }\end{array}$ \\
\hline Hep G2 (London) & $5.57 \pm 1.53$ & $1.11 \pm 0.31$ \\
Hep G2 (Brussels) & $3.43 \pm 0.95$ & $0.69 \pm 0.19$ \\
Mahlavu & $0.00 \pm 0.00$ & $0.00 \pm 0.00$ \\
\hline
\end{tabular}

are strictly reproducable. The highest rates of infection which could generally be obtained with the Hep G2 (London) cells are between 1 and $1.5 \%$.

A comparison of the parasitaemias in mouse blood obtained after infection with exoerythrocytic forms of $P$. berghei grown in hepatoma cells is shown in Table II. The OF1 mice become positive with the following ratios: Hep G2 (London): 7/7, Hep G2 (Brussels): 2/7, Mahlavu: 0/7. In both Hep G2 groups the OF1 begin to die at day 12: Hep G2 London): 1/7 and Hep G2 (Brussels): 1/7. In the Mahlavu group all mice survive at day 12 . These findings correspond well with those represented in Table I. The parasitaemias found in mice injected with Hep G2 (London) cells containing $P$. berghei are higher than in the case of the Brussels line and the Mahlavu line yields no parasitaemia at all. Also the number of infected mice per group and their survival as higher in the more susceptible cell lines: Hep G2 (London) > Hep G2 (Brussels) > Mahlavu. The correlation between the mean percentage of hepatoma cells harbouring mature schizonts in vitro and the mean corresponding parasitaemia reached in mice, 11 days p.i., is represented in Figure 1. This result illustrates the fact that the schizonts counted in our experiments are mature or at least give rise to viable, infectious merozoites.

TABLE II. - Parasitaemias of OF1 infected with Plasmodium berghei grown in human hepatoma cells for $58 \mathrm{~h}$, from day 5 to day 12 p.i. Mean values \pm s.e.m. $(\mathrm{n}=6$ or 7$)$. Cells resuspended in $0.3 \mathrm{ml}$ of complete MEM Rega 3.

\begin{tabular}{lccc}
\hline Time & Hep G2 (London) & Hep G2 (Brussels) & Mahlavu \\
\hline d5 & $0.00 \pm 0.00$ & $0.00 \pm 0.00$ & $0.00 \pm 0.00$ \\
d6 & $0.00 \pm 0.00$ & $0.00 \pm 0.00$ & $0.00 \pm 0.00$ \\
d7 & $0.01 \pm 0.00$ & $0.02 \pm 0.00$ & $0.00 \pm 0.00$ \\
d8 & $0.04 \pm 0.02$ & $0.10 \pm 0.07$ & $0.00 \pm 0.00$ \\
d11 & $3.66 \pm 0.80$ & $0.85 \pm 0.61$ & $0.00 \pm 0.00$ \\
d12 & $6.02 \pm 1.80$ & $1.30 \pm 1.20$ & $0.00 \pm 0.00$
\end{tabular}

The dimensions of the Hep G2 (London) cells proved to be as follows (mean values \pm s.e.m.):

- radius of the spheres $(n=79):(6.35 \pm 0.13) \mu \mathrm{m}$,

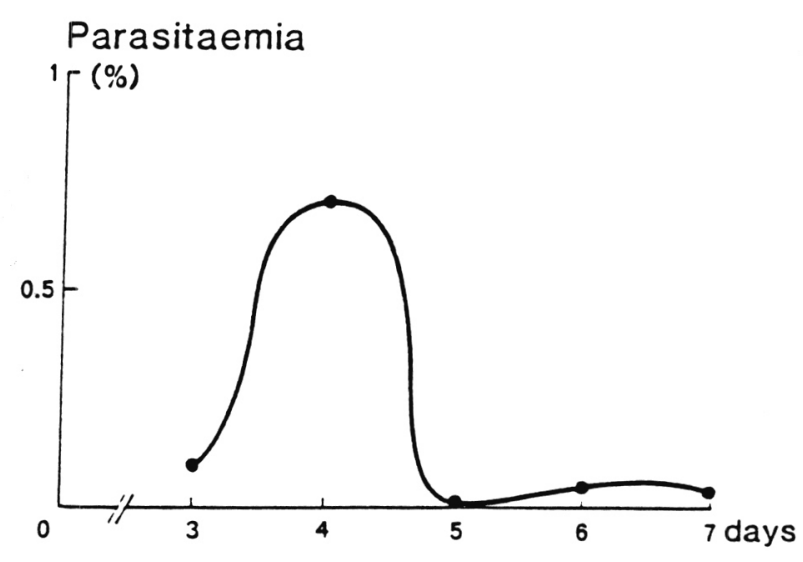

Fig. 1. - Correlation between the mean number of hepatoma cells with full-grown Plasmodium berghei schizonts $(n=7)$ and the mean parasitaemia in OF1 on day 11 after infection with exoerythrocytic forms developed in the corresponding line of hepatoma cells $(n=7) . \mathrm{L}=$ Hep G2 (London), B = Hep G2 (Brussels), $\mathrm{M}=$ Mahlavu.

- small diameter of the ellipsoids $(n=21)$ : (12.18 \pm 0.60$) \mu \mathrm{m}$,

- large diameter of the ellipsoids $(n=21)$ : (15.66 \pm 0.81$) \mu \mathrm{m}$.

This results in an overall cell volume of $(1102.75 \pm 26.38)$ $\mu \mathrm{m}^{3}(n=100)$. If all cells were considered as spheres, they would have an average radius of $6.41 \mu \mathrm{m}$. The dimensions of these suspended cells have the same order of magnitude of those of the infecting $P$. berghei sporozoites (Verhave and Meis 1984). When growing in monolayers their dimensions are still comparable. Cells in an average culture, having reached the stage of confluence and containing e.g. $5 \times 10^{6}$ cells per $25 \mathrm{~cm}^{2}$, would each take up a surface of $500 \mu \mathrm{m}^{2}$. If considered as cylinders, they would have a radius of $12.62 \mu \mathrm{m}$ and a height of $2.21 \mu \mathrm{m}$.

The growth curve of the Hep G2 (London) cells is represented in Figure 2. The mean cell density of trypsinized monolayers in $25 \mathrm{~cm}^{2}$ culture flasks in given at $1,2,3$, $4,5,6,7,8,10,11,12$ and 15 days after initiating a new monolayer. The growth curve can mathematically be characterized as follows ( $\mathrm{y}=$ number of cells per $\mu \mathrm{m}^{3}$, $\mathrm{t}=$ time in days, $\mathrm{r}=$ correlation coefficient):

$$
\begin{aligned}
& \text { - lag phase: } \mathrm{y}=200.00 ; \\
& \text { - log phase: } \mathrm{y}=336.03 \mathrm{t}-268.14(\mathrm{r}=0.9890) ; \\
& \text { - plateauphase: } \mathrm{y}=-27.03 \mathrm{t}+1646.91(\mathrm{r}=-0.3831) \text {. }
\end{aligned}
$$

The lag phase is relatively short: the cell density remains at the initial level during $1.39 \mathrm{~d}$ or $33.44 \mathrm{~h}$ (intersection between lag phase and log phase). The log phase lasts $3.88 \mathrm{~d}$ or $93.12 \mathrm{~h}$ (segment between intersections with lag phase and plateau phase). The slope of the log phase amounts to 336.03 cells $/ \mu \mathrm{m}^{3} /$ day. This value results in a population doubling time (PDT) (the time taken for the culture to increase two-fold in the middle of the exponential, i.e. 


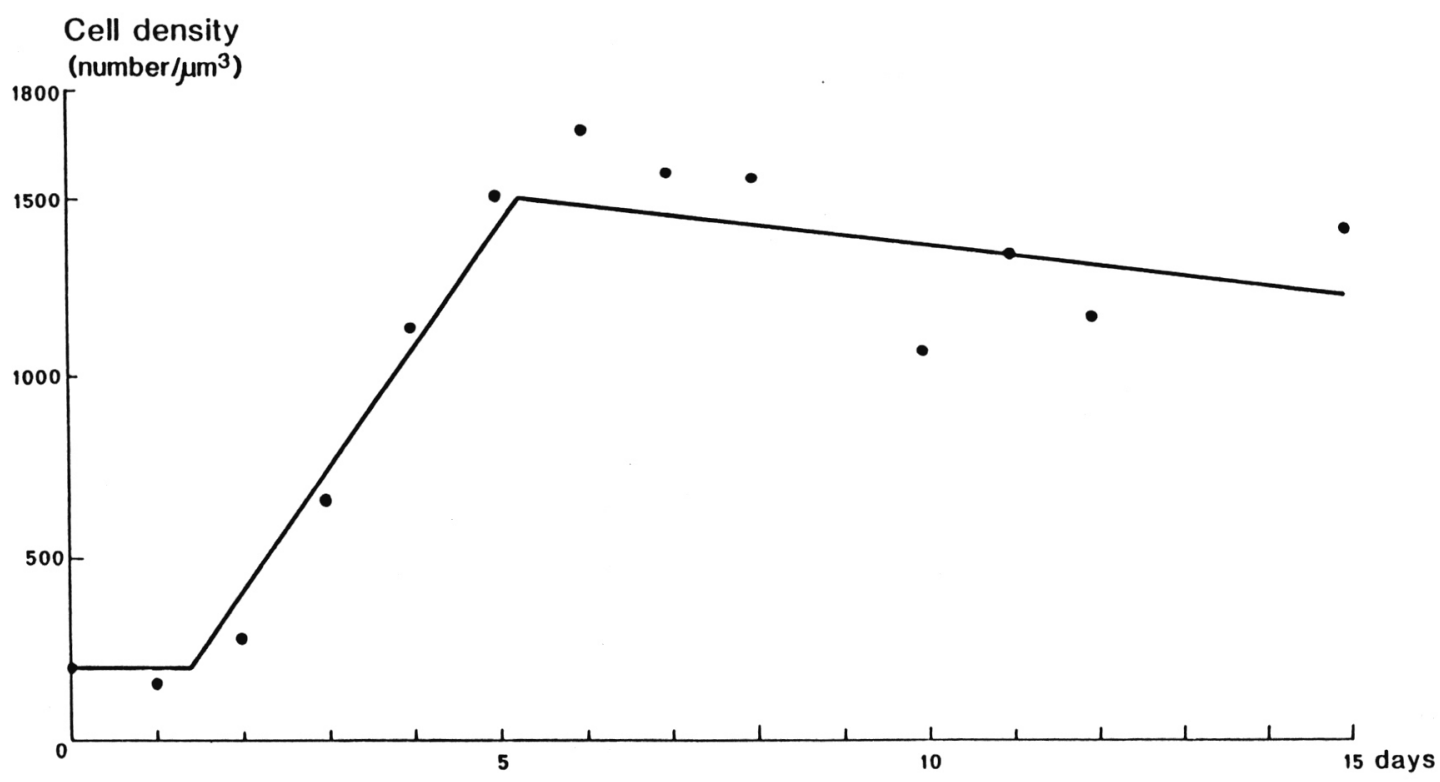

Fig. 2. - Growth curve of Hep G2 (London) cells. Cell density expressed as number of cells $/ \mu \mathrm{m}^{3}$ in culture flasks of $25 \mathrm{~cm}^{2}$. Initial inoculum: $10^{6}$ cells. Countings in an improved double Neubauer chamber. Four cultures, each counted 4 times.

TABLE III. - Influence of the FCS concentration on the growth of Hep 62 cells in vitro. Growth medium: MEM Rega 3 supplemented with $1 \%$ L-glutamine and FCS. Cell density expressed as number of cells present in $25 \mathrm{~cm}^{2}$ monolayers. Countings in an improved double Neubauer chamber. Four cultures per sample, each counted 4 times. Mean values \pm s.e.m. $(\mathrm{n}=16)$. Significance level of the differences with $48 \mathrm{~h}, 0 \% \mathrm{FCS}$ in oneway ANOVA.

\begin{tabular}{cccc}
\hline Time $(h)$ & $\%$ FCS & Number of cells & Significance level \\
\hline 0 & 10 & $3,412500 \pm 183,000$ & - \\
48 & 10 & $7,132000 \pm 244,500$ & - \\
48 & 8 & $7,025000 \pm 242,000$ & 0.7676 \\
48 & 6 & $7,312500 \pm 282,500$ & 0.6377 \\
48 & 4 & $6,690500 \pm 277,000$ & 0.3442 \\
48 & 2 & $7,056500 \pm 233,500$ & 0.8323 \\
48 & 0 & $6,058500 \pm 277,500$ & 0.0060 \\
\hline
\end{tabular}

at $3.33 \mathrm{~d}$ ) of $1.83 \mathrm{~d}$ or $43.92 \mathrm{~h}$. Based upon this value the Hep G2 (London) cells can be classified amongst adherent continuous cell lines with moderate to low growth rate (Freshney 1987). The log phase ends after 5.27 days of growth and the population reaches a maximum or saturation density of 1502.74 cells $/ \mu \mathrm{m}^{3}$. Near the end of the exponential phase the cultures have reached the stage of confluence and start to form only very locally some multilayers. Due to density limitation and the limitation of available nutrients a real steady state or a plateau s.s. is not attained.

In Table III the effect of the presence of FCS in the growth medium of Hep G2 (London) cells is demonstrated. The mean number of cells in $25 \mathrm{~cm}^{2}$ culture flasks is mea- sured after $48 \mathrm{~h}$ of culture in medium containing $0,2,4$, 6,8 or $10 \%$ FCS. At short notice ( $48 \mathrm{~h}$ of culture) the effect of diminishing the FCS concentration is not very pronounced. Eight, 6, 4 and $2 \%$ yield no significant differences with the standard concentration (10\%), expressed in numbers of harvested cells. Only total omission of calf serum results in a significant $(\mathrm{P}<0.01)$ but not very dramatic decrease of the growth rate. Other authors report the development of defined serum-free media which could support growth of Hep G2 cells and were supplemented with various factors (Adeli and Sinkevitch 1990).

Hepatoma cells infected with sporozoites of $P$. berghei during an incubation time of $2 \mathrm{~h}$ with a sporozoite suspension at the beginning of the experiment showed no changes in their growth speed when compared with cultures of control cells which had had no contact with sporozoites at all. Cells of both types of five-day-old cultures were trypsinized, washed and resuspended after $58 \mathrm{~h}$ of culture in standard medium, and counted in an improved double Neubauer chamber. Each time 4 cultures $\left(25 \mathrm{~cm}^{2}\right)$ were counted 4 times. The mean cell numbers per culture \pm s.e.m. ( $n=16$ ) were as follows: non-infected cells: $7,416,667 \pm$ 316,950; infected cells: $6,987,500 \pm 308,000$. The difference between these numbers proved to be not significant in a one-way analysis of variance (significance level $=0.3516$ ).

In Figure 3 the influence of the age of Hep G2 (London) cells on the development of $P$. berghei is visualized. The parasitaemia in OF1 mice is measured 8 days after infection of the host cells. Although the parasitaemias are still very low at day 8 it appears clearly that Hep G2 (London) cells are most susceptible for infection with sporozoites on the fourth day after subculturing them in the described 


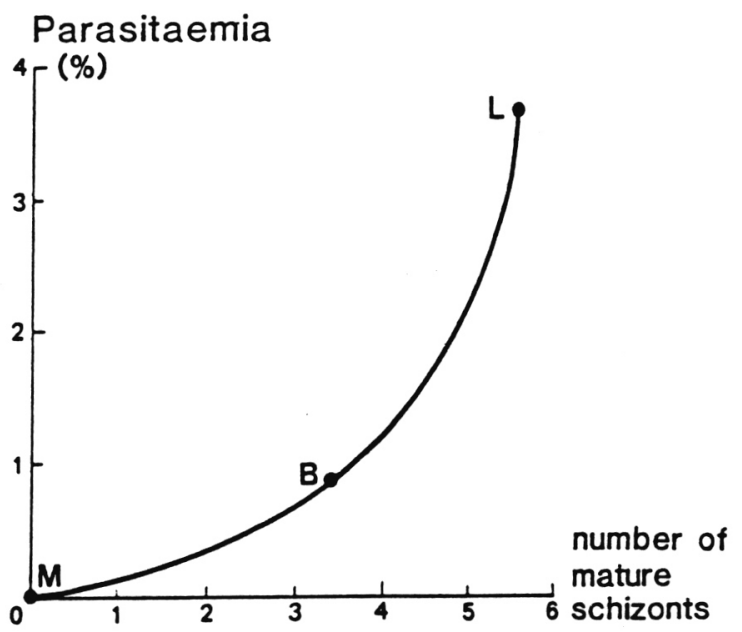

FIG. 3. - Dependency of the development of the exoerythrocytic forms of Plasmodium berghei on the age of the host cells. Incubation of Hep G2 (London) cells during $2 \mathrm{~h}$ with $P$. berghei sporozoites. Parasitaemia of OF1 mice, 8 days after infection with in vitro developed exoerythrocytic forms. Four cultures and 4 mice per group.

circumstances. However, since the maximal number of mice becomes positive in all the other groups too, also younger (3 days) and older (5-7 days) hepatoma cells are suitable for this type of experiments.

In order to measure the seeding efficiency of Hep G2 (London) cells a $25 \mathrm{ml}$ dilution containing $50 \times 10^{4}$ cells $(5 \mathrm{ml}$ was used as inoculum for 5 fresh cultures $\left(2 \times 10^{4}\right.$ cells $\left./ \mathrm{cm}^{2}\right)$. The cells were harvested $20 \mathrm{~h}$ later and counted 4 times. The mean values \pm s.e.m. $(n=20)$ amounted to $320,000 \pm 16,416$ cells/culture, resulting in a seeding efficiency of $(64.00 \pm 3.28) \%$. This means that about two thirds of the cells can be recovered when subculturing Hep G2 (London) cells with inocula in the range of $2 \times 10^{4} \mathrm{cells} / \mathrm{cm}^{2}$.

The measurement of the plating efficiency was prepared as follows. Eight wells of a microtiter plate were inoculated with $10 \mu \mathrm{l}$ of a dilution of Hep G2 (London) cells, prepared in two steps and containing 10 cells/well or 37.5 cells $/ \mathrm{cm}^{2}$. The cultures were observed after $4,8,14$ and 22 days. The plating efficiency could not be calculated since no colony forming was detected under these circumstances. However, its value is not necessarily zero, but somewhere between 0 and $10 \%$. Indeed, this supposition has been confirmed in the cloning experiment. In the second experiment 6 columns of 8 wells were incubated with $100 \mu$ l suspension corresponding with respectively 50 , $100,200,300,400$ and 500 cells $/ \mathrm{cm}^{2}$. Colony formation was observed after 5 days. The lowest density which gave positive results was 100 cells $/ \mathrm{cm}^{2}$. The colony forming capacity was strongly dependent on the initial cell density. Comparable results were obtained with $500 \mu \mathrm{l}$ suspensions in
24 wells multidishes, with an initial density between 50 and 100 cells $/ \mathrm{cm}^{2}$.

The results of the cloning experiment with Hep G2 (London) cells are shown in Table IV. The visually detectable formation of colonies begins slowly between days 4 and 8 after inoculation, rises after day 8 and reaches a maximum at day 15. After that, a part of the very young colonies is apparently aborted. Indeed, at day 21 the total number has decreased and tends to reach a final value around day 29. At the end of the experiment 12 colonies are counted. Seven of them appeared to be in good condition and were used as inoculum to start subcultures. Calculating the plating efficiency of Hep G2 (London) cells (initial inoculum $=3.6$ cells $/ \mathrm{cm}^{2}$ ) based on these results would yield a value of $12.50 \%$ in the first case, or based on the number of subcultured colonies a more reliable value or $7.29 \%$. This classifies the Hep G2 (London) cells amongst the continuous cell lines with low plating efficiency (Freshney 1987). Strictly spoken, the final value of $7.29 \%$ can be considered as the cloning efficiency, since it was obvious that each colony grew from a single cell.

TABLE IV. - Number of colonies of Hep G2 (London) cells formed in 12 volumns of 8 wells of a microtiter plate. Inoculum: $200 \mu \mathrm{l}$ suspension containing 1 cell/well. ${ }^{*}=$ healthy looking colonies which could readily be used as inoculum. Mean values $(\mu) \pm$ s.e.m.

\begin{tabular}{cccccc}
\hline & \multicolumn{5}{c}{ Number of colonies formed } \\
Column & $d 4$ & $d 8$ & $d 15$ & $d 21$ & $d 29$ \\
& & & & & \\
1 & 0 & 0 & 1 & 0 & 0 \\
2 & 0 & 0 & 2 & 1 & $1^{*}$ \\
3 & 0 & 0 & 1 & 1 & 1 \\
4 & 0 & 0 & 1 & 0 & 0 \\
5 & 0 & 0 & 2 & 1 & $1^{*}$ \\
6 & 0 & 0 & 2 & 2 & $2\left(1^{*}\right)$ \\
7 & 0 & 0 & 2 & 2 & $1^{*}$ \\
8 & 0 & 1 & 4 & 4 & $3\left(2^{*}\right)$ \\
9 & 0 & 1 & 2 & 1 & 1 \\
10 & 0 & 0 & 1 & 1 & 0 \\
11 & 0 & 1 & 1 & 1 & $1^{*}$ \\
12 & 0 & 1 & 2 & 1 & 1 \\
\hline$\mu \pm$ s.e.m. & $0.0 \pm 0.0$ & $0.3 \pm 0.1$ & $1.8 \pm 0.3$ & $1.3 \pm 0.3$ & $1.0 \pm 0.2$ \\
$(n=12)$ & & & & & \\
\hline
\end{tabular}

Table $V$ represents the growth of Hep G2 (London) cells in the wells of a microtiter plate under the influence of pre-conditioned medium. As in the case of the cloning experiment an initial rise of colony formation is observed, followed by a later decrease. This happened with all treatments. On both observation days the best results are obtained with $100 \%$ fresh medium. A smaller number of colonies is formed when the medium is composed of $50 \%$ fresh and $50 \%$ pre-conditioned MEM Rega 3. Eventually, 
TABLE V. - Effect of pre-conditioned complete MEM Rega 3 medium on the adherence of Hep G2 (London) cells on a substrate (12 columns of 8 wells) and the subsequent formation of colonies. $100 \% \mathrm{~F}=$ fresh medium; $50 \% \mathrm{~F}=$ fresh $+50 \%$ pre-conditioned medium; $0 \% F=$ pre-conditioned medium. Pre-conditioned medium obtained from 7-day-old cultures. Mean values $(\mu) \pm s . e . m$.

\begin{tabular}{|c|c|c|c|c|c|c|}
\hline \multirow[t]{3}{*}{ Column } & \multicolumn{3}{|c|}{ Number of adhering cells } & \multicolumn{3}{|c|}{ Number of colonies formed } \\
\hline & \multicolumn{2}{|c|}{ day 6} & \multirow[b]{2}{*}{$0 \% F$} & \multicolumn{2}{|c|}{ day 14} & \multirow[b]{2}{*}{$0 \% F$} \\
\hline & $100 \% F$ & $50 \% F$ & & $100 \% F$ & $50 \% F$ & \\
\hline 1 & 3 & 4 & 1 & 1 & 0 & 0 \\
\hline 2 & 3 & 3 & 3 & 3 & 0 & 0 \\
\hline 3 & 4 & 4 & 2 & 1 & 0 & 0 \\
\hline 4 & 5 & 1 & 0 & 3 & 1 & 0 \\
\hline $\begin{array}{c}\mu \pm \text { s.e.m. } \\
(n=4)\end{array}$ & $3.8 \pm 0.5$ & $3.0 \pm 0.7$ & $1.5 \pm 0.6$ & $2.0 \pm 0.6$ & $0.3 \pm 0.3$ & $0.0 \pm 0.0$ \\
\hline
\end{tabular}

TABLE VI. - Recovery of Hep G2 (London) cells after a stay of defined duration in the intraperitoneal cavity of OF1. Countings before and $24 \mathrm{~h}$ after i.p. injection of suspensions $\left(175 \mathrm{~cm}^{2}\right)$. Four suspensions per point, each counted 6 times. Mean values \pm s.e.m. $(\mathrm{n}=24)$.

\begin{tabular}{cccc}
\hline $\begin{array}{c}\text { Duration } \\
\text { of stay }(h)\end{array}$ & $\begin{array}{c}\text { Number of } \\
\text { injected cells }\end{array}$ & $\begin{array}{c}\text { Number of } \\
\text { recovered cells }\end{array}$ & $\begin{array}{c}\% \text { of recovered } \\
\text { cells }\end{array}$ \\
\hline 2 & $33.08 \pm 1.81$ & $6.16 \pm 0.63$ & 18.62 \\
4 & $35.54 \pm 2.70$ & $5.64 \pm 1.23$ & 15.87 \\
6 & $45.29 \pm 3.20$ & $6.82 \pm 0.63$ & 15.06 \\
8 & $33.04 \pm 2.14$ & $0.83 \pm 0.18$ & 2.51 \\
10 & $40.58 \pm 2.69$ & $1.83 \pm 0.05$ & 4.51 \\
24 & $40.42 \pm 2.84$ & $0.05 \pm 0.01$ & 0.01 \\
\hline
\end{tabular}

the cells are no longer able to form any colonies at all in a totally pre-conditioned medium.

The results of the experiment concerning the recovery of Hep $\mathrm{G} 2$ (London) cells in OF1 mice are given in Table VI. In any case only a limited part of the injected cells could be recovered after their stay in the intraperitoneal cavity. Many of them must have been attacked by the immune system of the host. In other experiments free parasites must have undergone phagocytosis as well as it as shown in vitro for sporozoites (Danforth et al. 1980) and exoerythrocytic stages (Weathersby 1985). An other part of the hepatoma cells probably did not survive the new circumstances. Finally, the number of counted cells must be an underestimation since a fraction of the present cells is likely not attainable for rinsing of the i.p. cavity. After a stay of $2 \mathrm{~h}$ e.g., about 1 out of 5 cells can be recovered. This proportion decreases only very slowly between 2 and $6 \mathrm{~h}$. After a prolonged stay of more than $6 \mathrm{~h}$ however, it falls sharply and reaches only a few percents of the original number after 8 or $10 \mathrm{~h}$. If the cells are permitted to stay in the i.p. cavity for $24 \mathrm{~h}$ only very few of them can be recovered.

The results of the survival experiment connected with the former one are displayed in Table VII. All Hep G2 (London) cultures, recovered after a stay with durations up to $10 \mathrm{~h}$ in OF1 mice contain living cells, viable enough to proliferate in vitro. Only the very small fraction of cells, recovered after a stay of $24 \mathrm{~h}$ proves to be less viable: 3 out of the 4 cultures do not survive. This phenomenon however could also be due to the well-known fact that the survival of cells, when plated at low densities, falls in all but a few cell lines. The time lapse between recovery of the cells and the point where they reach near confluence in vitro can be considered as reasonable after stays up to $6 \mathrm{~h}(4.00-8.50 \mathrm{~d})$. Only when much less cells coulb be harvested $(8-24 \mathrm{~h})$ this time is prolonged considerably (14.50-31.75 d). Subsequent subculturing reveals that all cells have preserved their status of viability: the time interval before a new near confluence is attained is normal in all cases $(4.75-8.00 \mathrm{~d})$.

TABLE VII. - Viability of Hep G2 (London) cells after a stay of defined duration in the intraperitoneal cavity of OF1. Time needed for reaching near confluence (NC) after recovery $(R)$ and after subsequent subculture (1:5) (S). Mean values \pm s.e.m. ( $\mathrm{n}=4)$.

\begin{tabular}{ccrc}
\hline $\begin{array}{c}\text { Duration } \\
\text { of stay }(h)\end{array}$ & $\begin{array}{c}\text { Number of } \\
\text { viable cultures }\end{array}$ & $\begin{array}{c}\text { Time between } \\
R \text { and } N C(d)\end{array}$ & $\begin{array}{c}\text { Time between } \\
S \text { and } N C(d)\end{array}$ \\
\hline 2 & 4 & $4.00 \pm 0.00$ & $4.75 \pm 0.50$ \\
4 & 4 & $8.50 \pm 2.72$ & $5.50 \pm 0.65$ \\
6 & 4 & $5.75 \pm 1.03$ & $4.75 \pm 0.48$ \\
8 & 4 & $14.50 \pm 4.09$ & $8.00 \pm 1.22$ \\
10 & 4 & $31.75 \pm 9.25$ & $5.25 \pm 0.63$ \\
24 & 1 & $25.00 \pm 0.00$ & $6.00 \pm 0.00$ \\
& & &
\end{tabular}




\section{DISCUSSION}

In the majority of the experiments concerning human hepatoma cells and their infection with Plasmodium sporozoites the Hep G2 line has been used. However, since the time of the isolation of the line (1975), its subsequent description (Aden et al. 1979; Knowles et al. 1980) and the establishment of the fact that many normal hepatocyte functions were conserved, research in the direction of selection of sublines was rather limited. A single cell clone, Hep G2-A16, derived from the parent Hep G2 line has been isolated (Schwartz et al. 1981) and is till now the only one available on a wider scale and useful in malaria research (Hollingdale et al. $1983 b$ and $c$ ). According to recent findings however, superior invasion indices, parasite growth and survival have been recorded for $P$. berghei in lines of Hep G2 other than the clone A16 (Sinden et al. 1990).

We have taken into account the possibility that cell populations, although originating from the same mother line, gradually change their characteristics in vitro in slightly different laboratory conditions and after long periods of time. The possibility of phenotypic variation in sublines of Hep G2 obtained from various laboratories has recently been confirmed with cells which displayed certain differences in their morphology and in plasma protein synthesis (Iwasa et al. 1990). The two Hep G2 populations used in our experiments have been cultured in London and Brussels respectively, both since at least several years. A pronounced difference in susceptibility for $P$. berghei sporozoite invasion and/or mature schizont development was demonstrated, probably due to loss of capacities in the Brussels line. An other Hep G2 subpopulation, kept at the Katholieke Universiteit te Nijmegen. The Netherlands, was compared with out London line too. Again, the London line was proved to be the more susceptible one (Verhave, personal communication). Frequently, a yield of 1-1.5\% of infected cells was obtained and exceptionally even more than $2 \%$. For comparison: about $0.1 \%$ of primary cultures of rat hepatocytes could be infected (Pirson 1982). For other cell types such as brain, liver, lung or heart embryonic cells from different species, $0.01 \%$ was to be considered as a high infection (Hollingdale et al. 1983a; Sinden and Smith 1980).

For 2 to 3-day-old Hep G2-A16 cells a yield of about 100 exoerythrocytic parasites $/ \mathrm{cm}^{2}$ was reported at $48 \mathrm{~h}$ after the sporozoite invasion (Hollingdale 1983c). We obtain much higher values in comparable circumstances. Even if we consider the distinct dependency from the age of the hepatoma cells the susceptibility of our cells for $P$. berghei sporozoite invasion and development of exoerythrocytic forms must be higher than in the case of the Hep G2-A16 cells.

Our $P$. berghei parasites proved to be infectious to mice after a growth period of $58 \mathrm{~h}$ in hepatoma cells. We have shown that it even was the case for younger forms, e.g.
$48 \mathrm{~h}$ old (data not shown). We have confirmed the presence of infectious merozoites in our $58 \mathrm{~h}$ cultures in an experiment where they were intravenously injected in OF1 mice, which became subsequently positive (results not shown). Indeed, it seems unlikely to us that exoerythrocytic schizonts are able to survive in the blood stream of the host for many hours. Certain authors described the formation of segmenters (Meis et al. 1985) with release of exoerythrocytic merozoites after 68-72 h (Aikawa et al. 1984; Hollingdale et al. 1983c; Hollingdale 1988) or after 48-60 h (Suhrbier et al. 1987 and 1989b). We wondered if, besides this apparent asynchronicity, it is possible that the host cells of the exoerythrocytic parasites would survive in the intraperitoneal cavity for a certain time, allowing immature forms to develop to full-grown schizonts inside OF1 mice. Checking this hypothesis, we succeeded in recovering 15-20\% of intraperitoneally injected inocula of Hep G2 (London) cells after a stay lasting up to $6 \mathrm{~h}$. Delaying the harvest of cells caused a rather dramatic decrease of the yield, but still a significant number of cells could be counted, even after $24 \mathrm{~h}$. And even more important, the majority of the harvested cells had kept their integrity and viability. This was proved by testing their ability for cell proliferation in vitro. Monolayer formation was successful throughout the whole experiment. And although it was somewhat more difficult after $24 \mathrm{~h}$, this effect was probably due to the low cell densities, rather than to a diminished viability.

So it appears that the mouse intraperitoneal cavity is perhaps not the ideal but at least a suitable environment for human hepatoma cells. It is reasonable to assume that $P$. berghei infected cells survive in the same circumstances and permit the further intracellular development of the parasites. More arguments for this hypothesis are given in an experiment where $P$. berghei infected cells were i.p. injected in OF1 mice after relatively short incubation times in vitro (2, 6 and $24 \mathrm{~h}$ ). Part of the mice became positive in less than 8 days, even after $2 \mathrm{~h}$ incubation, where only very young trophozoites could have been present (unpublished results).

Human hepatoma cells harbouring exoerythrocytic forms of $P$. berghei and i.p. injected in OF1 mice do most probably not infect the host in a single event, due to the merozoites present at that defined time, but on the contrary keep on releasing merozoites during many hours and thus constantly provide the host with infectious parasites.

$P$. berghei sporozoites have about the same length (Verhave and Meis 1984) as the calculated radius of the Hep G2 (London) cells if their surface is considered as being isodiametric. In one experiment taken as an example a suspension containing 168,000 sporozoites was overlaid onto a $25 \mathrm{~cm}^{2}$ monolayer, representing $5 \times 10^{6}$ cells. This represents a ratio of 1 sporozoite for 30 hepatoma cells. According to others, approximately $10 \%$ of the sporo- 
zoites attached to Hep G2-A16 cells in comparable circumstances and about $80 \%$ of the invaded sporozoites transformed into trophozoites (Hollingdale 1988). This brings us to a ratio of 1 developping intracellular parasite per 375 hepatoma cells or $0.27 \%$. Our Hep G2 (London) cells yield an average infection of $1 \%$. These numbers correspond with $8 \%$ sporozoites transformed into schizonts in the cited example and about $30 \%$ in our example. Recently two continuous cell lines have been derived from the liver of BALB/c mice (Long et al. 1989). Both supported growth and complete development of $P$. berghei liver stages in vitro and permitted the transformation of $0.3 \%$ and $0.05 \%$ sporozoites respectively. Calculated ratios of transformed sporozoites should be interpreted with caution however, since our unpublished results show that saturation is easily attained when an excess of sporozoites is added.

Analysis of the growth curve of the Hep G2 (London) cells reveals an exponential phase lasting for $93 \mathrm{~h}$, with a PDT time of $44 \mathrm{~h}$. Kelly and Darlington (1989) produced the following values with a Hep G2 cell population obtained from the Wistar Institute, Philadelphia: a log phase of $120 \mathrm{~h}$ and a PDT of $24 \mathrm{~h}$ for low density cultures $(<200,000$ cells $/ \mathrm{cm}^{2}$ ). Especially the difference in PDT is remarkable. Our cells grow about twice as slow in the log phase. This changing growth pattern reflects an other difference between subpopulations kept in varying circumstances. The high degree of contact inhibition contributing to a pronounced density limitation is obvious in the two cases. The period of rapid division ends abruptly and passes into a period of slow growth in the described case and into a period of slow decline in our case. The same cited authors obtain a plating efficiency greater than $80 \%$. If they mean plating efficiency s.s. a more than dramatic discrepancy with our value $(7.29 \%)$ would be the result. But based upon the description of their experiments it is more than likely they actually mean seeding efficiency and in this case their value would lie about $20 \%$ higher than ours $(<80 \%$ vs $64 \%$ ), a result compatible with the already stated difference in growth pattern.

The growth of embryonic rat brain cells functioning as hosts for $P$. berghei parasites is severely affected by the addition of teased mosquito glands (Sinden and Smith 1980). Not only the normal multiplication rate was influenced but also the survival of the cells. Clearly the cause was the presence of the glands themselves and not the infection with $P$. berghei since uninfected glands caused the same effect. For the same purpose the growth of Hep G2 (London) cells was monitored after incubation with infected $A$. stephensi salivary glands. No inhibition of the growth of the hepatoma cells nor any decline in cell number could be stated.

Tests were undertaken to test the dependency of cell growth on the presence of FCS. Retarding the growth of the host cells could be interesting in experiments involving development of exoerythrocytic $P$. berghei stages, for evaluation purposes. Concentrations as low as $2 \%$ were proved to be sufficient to sustain cell proliferation at the normal rate for at least 2 days. A medium containing $10 \%$ FCS permitted the same growth rate as a complete medium supplemented with many organic and inorganic factors in cultures of an other subpopulation of Hep G2 cells, but was significantly better than the same basal medium totally depleted of FCS (Darlington et al. 1987). We report a corresponding decrease of growth of the Hep G2 (London) cells at short notice when completely omitting the FCS. The authors cited above warn for the possibility that prolonged cultivation of Hep G2 cells in the absence of hormones, growth factors and FCS results in the appearance of a new phenotype (with a very different quantitative production of certain proteins) that is not reversible by the replacement of serum. So this changes in the cell population probably reflect a selective pressure. The idea that modifications of the culture conditions or even the utilization of defined media for longer times could be the cause of essential and irreversible alterations of the population characteristics is consistent with our statement that Hep G2 subpopulations kept in different laboratories can significantly differ in their capacity for serving as host cells for $P$. berghei exoerythrocytic forms. The pattern of colony formation of Hep G2 (London) cells shows similarities with the growth curve. However, the time scale is different: the lag phase is significantly extended (4-8 days $v s 1$ day) and the peak is later reached ( 15 days $v s 5$ days). Till now, only the Hep G2-A16 clone has been derived from the original line and frequently been used for malaria research purposes. Seen the described obvious shift of the average characteristics of Hep G2 subpopulations (susceptibility for infection, biochemical properties and growth parameters) we believe that cloning should be the best tool in a selection procedure, combined with already described methods (Corcos and Weiss 1988). Cloning of the Hep G2 (London) cells proved to be not too easy (low cloning efficiency), but feasible. More subpopulations, clones and subclones should systematically be compared in the future in order to take full advantage of their potential and caution is advised when interpreting and evaluating results obtained with cells from different sources.

Acknowledgments. - The authors wish to express their gratitude to Mrs. Anne Correwyn, Mrs. Chantal van Overmeir, Mr. Luc Hendrix, Mr. Guy Lapaire and Mr. Georges Timperman for their skilful and dedicated technical assistance.

They thank the following persons for kindly providing the human hepatoma cell lines: Dr. R. Sinden (Imperial College, London) for the Hep G2 (London) line, Dr. S. Rollin (Université Libre de Bruxelles) for the Hep G2 (Brussels) line and Dr. J. Desmyter and Mrs. VermeYlen (Katholieke Universiteit te Leuven) for the Mahlavu line. 


\section{REFERENCES}

Adeli K., Sinkevitch C. : Secretion of apolipoprotein B in serumfree cultures of human hepatoma cell line, Hep G2. FEBS Letters, 1990, 263, 345-348.

Aden D. P., Fogel A., Plotkin S., Damjanov I., Knowles B. B. : Controlled synthesis of HBsAg in a differentiated human liver carcinoma-derived cell line. Nature, 1979, 282, 615-616.

Aikawa M., Schwartz A., Uni S., Nussenzweig R., Hollingdale M. : Ultrastructure of in vitro cultured exoerythrocytic stage of Plasmodium berghei in hepatoma cell line. Am. J. Trop. Med. Hyg., 1984, 33, 792-799.

Bissell D. M., Arenson D. M., Maher J. J., Roll F. J. : Support of cultured hepatocytes by alaminin-rich gel. Evidence for a functionally significant subendothelial matrix in normal rat liver. J. Clin. Invest., 1987, 79, 801-812.

Buscher H.-P. : Defective drug uptake contributing to multidrug resistance in hepatoma cells can be evaluated in vitro. Klin. Wochenschr., 1990, 68, 443-446.

Corcos L., Weiss M. C. : Efficient one-step selection of hepatoma cell variants of a variety of phenotypes by use of aflatoxin B1. Differentiation, 1988, 38, 134-139.

Danforth H. D., Aikawa M., Cochrane A. H., Nussenzweig R. S. : Sporozoites of mammalian malaria: attachment to, interiorization and fate within macrophage. J. Protozool., 1980, 27, 193-202.

Darlington G. J., Kelly J. H., Buffone G. J. : Growth and hepatospecific gene expression of human hepatoma cells in a defined medium. In vitro Cellul. Develop. Biol., 1987, 23, 349-354.

Freshney R. I. : Culture of Animal Cells. A Manual of Basic Technique. Alan R. Liss, Inc., New York, 1987.

Gatmaitan Z., Jefferson D. M., Ruiz-Opazo N., Biempica L., Arias I. M., Dudas G., Leinwand L. A., Reid L. M. : Regulation of growth and differentiation of a rat hepatoma cell line by synergistic interactions of hormones and collagenous substrata. J. Cell Biol., 1983, 97, 1179-1190.

Geuze H. J., Slot J. W., Strous G. J. A. M. et al. : The pathway of the asialoglycoprotein-ligand during receptor-mediated endocytosis: a morphological study with colloidal gold/ligand in the human hepatoma cell line, Hep G2. European J. Cell Biol., 1983, 32, 38-44.

Hollingdale M. R., Leef J. L., McCullough M., Beaudoin R. L. : In vitro cultivation of the exoerythrocytic stage of Plasmodium berghei from sporozoites. Science, 1981, 213, 1021-1022.

Hollingdale M. R., Leland P., Leef J. L., Beaudoin R. L. : The influence of cell type and culture medium on the in vitro cultivation of exoerythrocytic stages of Plasmodium berghei. J. Parasitol., 1983a, 69, 346-352.

Hollingdale M. R., Leland P., Leef J. L., Schwartz A. L. : Entry of Plasmodium berghei sporozoites into cultured cells, and their transformation into trophozoites. Am. J. Frop. Med. Hyg., $1983 b, 32,685-690$.

Hollingdale M., Leland P., Schwartz A. L. : In vitro cultivation of the exoerythrocytic stage of Plasmodium berghei in a hepatoma cell line. Am. J. Trop. Med. Hyg., 1983c, 32, 682-684.

Hollingdale M. R., Collins W. E., Campbell C. C. : In vitro culture of exoerythrocytic parasites of the North-Korean strain of P. vivax in hepatoma cells. Am. J. Trop. Med. Hyg., 1986, 35, 275-276.

Hollingdale M. R., Ballou W. R., Aley S. B., Young J. F., Pancake S., Miller L. H., Hockmeyer W. T. : Plasmodium falciparum: elicitation by peptides and recombinant circumsporozoite proteins of circulating mouse antibodies inhibiting invasion of hepatoma cells. Exp. Parasitol., 1987, 63, 345-351.

Hollingdale M. R. : Biology and immunology of sporozoite inva- sion of liver cells and exoerythrocytic development of malaria parasites. Prog. Allergy, 1988, 41, 15-48.

Iwasa F., Galbraith R. A., Sassa S. : Phenotypic variation in human Hep G2 hepatoma cells: alterations in cell growth, plasma protein synthesis and heme pathway enzymes. Int. J. Biochem., 1990, 22, 303-310.

Jensen J. B., Trager W., Doherty J. : Plasmodium falciparum: continuous cultivation in a semiautomated apparatus. Exp. Parasitol., 1979, 48, 36-41.

Kelly J. H., Darlington G. J. : Modulation of the liver specific phenotype in the huma hepatoblastoma line Hep G2. In vitro Cellular and Developmental Biology, 1989, 25, 217-222.

Knowles B. B., Howe C. C., Aden D. P. : Human hepatocellular carcinoma cell lines secrete the major plasma proteins and hepatitis B surface antigen. Science, 1980, 209, 497-499.

Lambiotte M., Landau I., Thierry M., Miltgen F. : Développement de schizontes dans de hépatocytes de rat adulte en culture, après infestation in vitro par des sporozoites de Plasmodium yoelii. C. R. Acad. Sci. Paris, 1981, 293, 431-433.

Landau I., Mazier D., Baxter J., Millet P., Miltgen F., Druilhe P. : The culture of Plasmodium schizonts in hepatocytes. In "Primaquine: pharmacokinetics, metabolism, toxicity and activity » (W. H. Wernsdorfer and P. I. Trigg, Eds), pp. 139-143. UNDP/World Bank/WHO, John Wiley and Sons.

Le Ray D. : Structures antigéniques de Trypanosoma brucei (Protozoa, Kinetoplastida). Analyse immunoélectrophorétique et étude comparative. Ann. Soc. Belge Med. Trop., 1975, 55, 129-311.

Long G. W., Leath S., Schuman R., Hollingdale M. R., Ballou W. R., Kim Lee Sim B., Hoffman S. L. : Cultivation of the exoerythrocytic stage of Plasmodium berghei in primary cultures of mouse hepatocytes and continuous mouse cell lines. In vitro Cellel. Develop. Biol., 1989, 25, 857-862.

Mazier D., Beaudoin R. L., Mellouk S., Druilhe P., Texier B., Trosper J., Miltgen F., Landau I., Paul C., Brandicourt O., Guguen-Guillouzo, Langlois P. : Complete development of hepatic stages of Plasmodium falciparum in vitro. Science, 1984, $227,440-442$.

Meis J. F. G. M., Verhave J. P., Yap S. H., Meuwissen J. H. E. Th. : Fine structure of exoerythrocytic merozoite formation of Plasmodium berghei in the rat liver. J. Protozool, 1985, 32, 694-699.

Millet P., Landau I., Peters W. : In vitro testing of antimalarial exoerythrocytic schizontocides in primary cultures of hepatocyte. Mem. Inst. Oswaldo Cruz, 1986, 81, suppl. II, 135-141.

Muakkassah-Kelly S. F., Bieri F., Waechter F., Bentley P., Stäubli W. : Long-term maintenance of hepatocytes in primary culture in the presence of DMSO: Further characterization and effect of nafenopin, a peroxisome proliferator. Exp. Cell Res., 1987, 171, 37-51.

Pirson P. : Culture of the exoerythrocytic liver stages of Plasmodium berghei sporozoites in rat hepatocytes. Trans. R. Soc. Trop. Med. Hyg., 1982, 76, 422.

Schwartz A. L., Fridovich S. E., Knowles B. B., Lodish H. F. : Characterization of the asialoglycoprotein receptor in a continuous hepatoma line. J. Biol. Chem., 1981, 256, 8878-8881.

Sinden R. E., Smith J. : Culture of the liver stages (exoerythrocytic schizonts) of rodent malaria parasites from sporozoites in vitro. Trans. R. Soc. Trop. Med. Hyg., 1980, 74, 134-136.

Sinden R. E., Suhrbier A., Davies C. S., Fleck S., Hodivala K., Nicholas J. C. : The development and routine application of high density exoerythrocytic stage cultures of Plasmodium berghei. Bull. World Health Org. (In Press).

Strom S. C., Jirtle R. L., Jones R. S., Novicki D. L., Rosenberg M. R., Novotny A., Irons G., McLain J. R., Michalopoulos G. : Isolation, culture, and transplantation of human hepatocytes. J. Nat. Cancer Inst., 1982, 68, 771-778. 
Suhrbier A., Janse C., Mons B., Fleck S. L., Nicholas J., Davies C. S., Sinden R. E. : The complete development in vitro of the vertebrate phase of the mammalian malarial parasite Plasmodium berghei. Trans. R. Soc. Trop. Med. Hyg., 1987, 81, 907-909.

Suhrbier A., Holder A. A., Wiser M. F., Nicholas J., Sinden R. E. : Expression of the precursor of the major merozoite surface antigens during the hepatic stage of malaria. Am. J. Trop. Med. Hyg., 1989a, 40, 351-355.

Suhrbier A., Wiser M. F., Winger L., Harte P., Newton M. F., Hodivala K. J., Nicholas J., Sinden R. E. : Contrasts in antigen expression in the erytrocytic and exoerythrocytic stages of rodent malaria. Parasitology, 1989b, 99, 165-170.

Trager W., Jensen J. B. : Human malaria parasites in continuous culture. Science, 1976, 193, 673-675.

Turner B. M., Turner V. S. : Secretion of $\alpha 1$-antitrypsin by an established human hepatoma cell line and by human/mouse hybrids. Somatic Cell Genet., 1980, 6, 1-14.

Uni S., Aikawa M., Collins W. E., Campbell C. C., Holling- dale M. R. : Electron microscopy of Plasmodium vivax exoerythrocytic schizonts grown in vitro in a hepatoma cell line. Am. J. Trop. Med. Hyg., 1985, 34, 1017-1021.

Verhave J. P., Meis J. F. G. M. : The biology of tissue forms and other asexual stages in mammalian plasmodia. Experientia, 1984, 40, 1317-1329.

Weathersby A. B. : Plasmodium fallax: Phagocytosis of exoerythrocytic stages in tissue culture. J. Parasitol., 1985, 71, 556-558.

Wery M. : Studies on the sporogony of rodent malaria parasites. Ann. Soc. Belge Med. Trop., 1968, 48, 1-138.

World Health Organization: Exoerythrocytic and asexual bloodstage antigens of human malaria parasites: report of the tenth meeting of the scientific working group on the immunology of malaria. TDR/IMMAL/SWG (10)/88.3, 1988.

Zavala F., Hollingdale M. R., Schwartz A. L., Nussenzweig R. S., Nussenzweig V. : Immunoradiometric assay to measure the in vitro penetration of sporozoites of malaria parasites into hepatoma cells. J. Immunol., 1985, 134, 1202-1205. 